\title{
A subset of bone marrow stromal cells regulate ATP-binding cassette gene expression via insulin-like growth factor-I in a leukemia cell line
}

\author{
NADIA BENABBOU ${ }^{1}$, PEZHMAN MIRSHAHI $^{1}$, CAMILLE BORDU $^{1}$, ANNE-MARIE FAUSSAT $^{2}$, \\ RUOPING TANG ${ }^{3}$, AMU THERWATH ${ }^{1}$, JEANNETTE SORIA ${ }^{1}$, \\ JEAN-PIERRE MARIE $^{2}$ and MASSOUD MIRSHAHI ${ }^{1}$ \\ ${ }^{1}$ UMR, Paris Diderot, Paris 7 University, Lariboisiere Hospital, INSERM U965; ${ }^{2}$ Department of Hematology, \\ ${ }^{3}$ Tumor Bank 'Leukemia', Saint-Antoine Hospital, Paris, France
}

Received April 15, 2014; Accepted June 5, 2014

DOI: $10.3892 /$ ijo.2014.2569

\begin{abstract}
The importance of the insulin-like growth factor, IGF, as a signaling axis in cancer development, progression and metastasis is highlighted by its effects on cancer cells, notably proliferation and acquired resistance. The role of the microenvironment within which cancer cells evolve and which mediates this effect is far from clear. Here, the involvement of IGF-I in inducing multidrug resistance in a myeloid leukemia cell line, grown in the presence of bone marrow-derived stromal cells called 'Hospicells' (BMH), is demonstrated. We found that i) drug sensitive as well as resistant leukemia cells express IGF-I and its receptor IGF-IR. However, the resistant cells were found to secrete high levels of IGF-I. ii) Presence of exogenous IGF-I promoted cell proliferation, which decreased when an inhibitor of IGF-IR (picropodophyllin, PPP) was added. iii) BMH and IGF-I are both involved in the regulation of genes of the ATP binding cassette (ABC) related to resistance development (MDR1, MRP1, MRP2, MRP3 and BCRP). iv) The levels of ABC gene expression by leukemia cells were found to increase in the presence of increasing numbers of BMH. However, these levels decreased when IGF-IR was inhibited by addition of PPP. v) Co-culture of the drug-sensitive leukemia cells with $\mathrm{BMH}$ induced protection against the action of daunorubicin. This chemoresistance was amplified by the presence of IGF-I whereas it decreased when IGF-IR was inhibited. Our results underline the role of microenvironment in concert with the IGF-1 pathway in conferring drug resistance to leukemia cells.
\end{abstract}

Correspondence to: Dr Massoud Mirshahi, UMR, Paris Diderot, Paris 7 University, Lariboisière Hospital, INSERM U965, 41 bd de la Chapelle 75010, Paris, France

E-mail: massoud.mirshahi@inserm.fr

Key words: IGF signaling pathway, ATP binding cassette, hospicells, chemoresistance, leukemia

\section{Introduction}

A major problem in the treatment of leukemia is the appearance of multi-drug resistance (1). Chemoresistance often is at the origin of a major number of relapses which are mediated by the expulsion activity of the $\mathrm{ABC}$ pumps.

The microenvironment is intimately related to the development of drug resistance in cancer cells. However, the precise nature of molecular events in action between the stromal and leukemic cells remains still elusive. Chemoresistance of leukemic cells, besides the microenvironment is also controlled by the ATP binding cassette genes (ABC), notably ABCB1 (MDR1) which code for the P-gp protein. In a rather unorthodox series of experiments we identified recently the presence of a distinct population of stromal cells in the tumor microenvironment which we baptized 'Hospicells' (BMH). These cells were found to establish very particular relationship with HL60 (acute leukemia cell lines), MDA-MB-231-GFP (breast cancer cell line) and OVCAR-3GFP (ovarian cancer cell line) (2-7). In solid tumors, the very presence of Hospicells were found to confer drug resistance to cancer cells during chemotherapy via oncologic trogocytosis $(2,3)$, as a result of upregulation of ATP binding cassette gene family (4).

Hospicells by their presence promotes tumorigenicity and angiogenesis (5) besides influencing the immune response of tumor microenvironments $(6,7)$. A plethora of cell metabolic functions such as vasculogenic mimicry, cancer cell proliferation, inhibition of cell death and metastasis are known today to be influenced by IGF-1 (8-20).

This is the first report concerning the effect of IGF-I on the regulation of the ABC genes (MDR1, MRP1, MRP2, $M R P 3, M R P 5$ and $B C R P$ ) in leukemic cells when they are put in contact with a subset of bone marrow derived stromal cell named Hospicells.

\section{Materials and methods}

Cell culture. Four cell lines were used in this study, HL-60, (acute promyelocytic leukemia ATCC, CCL-240), K-562 (chronic myelogenous leukemia ATCC, CCL 243), K562 
and HL60 derived from K562/Dox and HL60/Dnr, which were developed as daunorubicin and doxorubicin resistant lines, respectively. These cells are deposited at the Leukemia Tumor Bank, Hôpital Saint Antoine, Paris. The phenotype for HL60 wild-type $\left(\mathrm{CD}_{13}{ }^{+}, \mathrm{CD}^{+} 5^{+}, \mathrm{CD}_{3}{ }^{+} \mathrm{CD} 3^{-}\right.$, $\mathrm{CD}^{-} 4^{-}, \mathrm{CD} 19^{-}, \mathrm{HLA}^{-\mathrm{Dr}}$ ) and for $\mathrm{K} 562$ wild-type (BCRAbl ${ }^{+}$ 'Philadelphia chromosome', CD13 ${ }^{+}$, glycophorin ${ }^{+}$and CD3', $\left.\mathrm{CD} 19^{-}\right)$were determined by flow cytometry. These two cell lines are routinely used as reference cells for chromosome mutation (K562-BCRAbl) and HL60 for leukemia cell endothelial protein-C receptor. All cell lines were cultured using RPMI-1640 containing 10\% fetal bovine serum (FBS), $1 \%$ L-glutamine $50 \mathrm{U} / \mathrm{ml}$ penicillin and $50 \mu \mathrm{g} / \mathrm{ml}$ streptomycin and incubated at $37^{\circ} \mathrm{C}$ in $5 \% \mathrm{CO}_{2}$ atmosphere.

Bone marrow Hospicells. Hospicells were isolated from eight AML bone marrows (Hôpital Hotel Dieu, Paris). The bone marrow-adherent mononuclear cell population (BMMNCs) isolation was carried out by Ficoll density gradient centrifugation as described (21). The contaminating monocytes in the mononuclear cell population were excluded by adhesion on plastic plates for $30 \mathrm{~min}$. Then, the non-adherent cells were collected and cultured for 2 weeks in wells coated with $0.2 \%$ gelatin in endothelial cell basal medium MV2 (Promocell, Heidelberg, Germany) supplemented with final concentrations of $1 \mathrm{~g} / \mathrm{ml}$ ascorbic acid, $10 \mathrm{ng} / \mathrm{ml} \mathrm{b}-F G F, 5 \mathrm{ng} / \mathrm{ml} \mathrm{EGF}$, $20 \mathrm{ng} / \mathrm{ml}$ insulin growth factor-1 (IGF-1), $0.5 \mathrm{ng} / \mathrm{ml}$ VEGF and $15 \%$ FBS. The bone marrow Hospicells were isolated as described (2-7).

Adhesion assay. Adherent BMMNCs $\left(10^{5}\right)$ were seeded in 6-well plates with their respective culture medium and left to adhere. After completion of cell adhesion, they were washed twice with PBS. HL60 $\left(3 \times 10^{6}\right)$ were plated onto the adherent cell monolayer at $37^{\circ} \mathrm{C}$ for $24 \mathrm{~min}$. Then, the supernatant containing non-adherent cells was discarded and the cell monolayer was again washed twice with PBS. The number of $\mathrm{BMH}$ in the adherent cell population, obtained after $24 \mathrm{~h}$ culture was evaluated. When 5 or more leukemic cells adhered to a single bone marrow stromal cell the latter was considered to be a Hospicell.

Treatment of cells with IGF-I and IGF-IR inhibitor. The leukemic cell lines were incubated with IGF-I $(200 \mathrm{ng} / \mathrm{ml})$ and IGF-IR inhibitor PPP (picropodophyllin, $1 \mu \mathrm{M}$ ) from Calbiochem (Paris).

Reverse transcription and polymerase chain reaction (RT-PCR). Total RNA was extracted with the Nucleospin RNA II kit (Macherey-Nagel EURL, Hoerdt, France). Reverse transcription was performed using M-MLV reverse transcriptase and oligo(dt) primers (Gibco-BRL, Paisley, UK). The polymerase chain reaction (PCR) was performed by Taq DNA polymerase (Gibco-BRL). Specific primers for $I G F-I$ (sense: 5'-AAA TCA GCA G TC TTC CAA C-3' and antisense: 5'-CTT CTG GGT CTT GGG CAT GT-3'); IGF-II (sense: 5'-AGT CGA TGC TGG CTT CTC A-3' and antisense: 5'-GTG GGC GGG GTCT TGG GTG GGT AG-3'); IGF-IR (sense: 5'-GAC ATC CGC AAC GAC TAT CAG-3' and antisense: 5'-GTA GTT ATT GGA CAC CGC ATC-3'); IGF-IIR (sense: 5'-TAC
AAC TTC CGG TGG TAC ACC A-3' and antisense: 5'-CAT GGC ATA CCA GTT TCC TCC A-3'); $M D R l$ (sense: 5'-GTT ATA GGA AGT TTG AGT TT-3' and antisense: 5'-AAA AAC TAT CCC ATA ATA AC-3'); $M R P$ (sense: 5'-AAT GCG CCA AGA CTA GGA AG-3' and antisense: 5'-ACG GGA GGA TGT TGA ACA AG-3'); $M R P 2$ (sense: 5'-CTG GTT GAT GAA GGC TCT GA-3' and antisense: 5'-CTG CCA TAA TGT CCA GGT TC-3'); MRP3 (sense: 5'-GCA GGT GAC ATT TGC TCT GA-3' and antisense: 5'-CCC TCT GAG CAC TGG AAG TC-3'); MRP5 (sense: 5'-GGA TAA CTT CTC AGT GGG-3' and antisense: 5'-GGA ATG GCA ATG CTC TAA AG-3'); $B C R P$ (sense: 5'-TTA GGA TTG AAG CCA AAG G-3' and antisense: 5'-TAG GCA ATT GTG AGG AAA ATA-3') and $\beta 2$-microglubulin (sense: 5'-CCA GCA GAG AAT GGA AAG TC-3' and antisense: 5'-GAT GCT GCT TAC ATG TCT CG-3'). The PCR products, along with a 100-bp DNA ladder, were analysed by electrophoresis on agarose gels containing ethidium bromide.

IGF expression by leukemic cells. The presence of proteins belonging to IGF family in cell lines was revealed by immunocytochemistry. Cells were seeded and fixed at 20,000 cells/well in glass bottom chamber slides (Nunc, Lab-Tek, Naperville, IL, USA). They were then permeabilized and incubated for $2 \mathrm{~h}$ at room temperature either with specific primary antibodies (dilution 1/200) anti-IGF-I, -II, -IR or -IIR (R\&D Systems, Minneapolis, MN, USA). After several washes, the cells were incubated successively with biotinylated secondary antibody and streptavidine coupled to fluorescein isothiocyanate (dilution 1/500), for $45 \mathrm{~min}$. Isotypic controls were performed concurrently and nuclei were DAPI-labeled. The cells were then visualized by fluorescence microscopy.

Analysis of P-gp expression. P-gp was studied by using UIC2 (Immunotech, France), monoclonal antibody, followed by labeling with a secondary antibody conjugated with phycoerythrin. Cells $\left(1 \times 10^{6}\right)$ were fixed and permeabilized using IntraPrep $^{\mathrm{TM}}$ (Beckman Coulter, Villepinte, France) as per the manufacturer's instructions. Fluorescence was measured and analyzed by flow cytometry. Protein expression for each transporter was quantified as the mean fluorescence intensity (MFI) shift (ratio of the MFI of antibody and isotype control). All experiments were performed in triplicate.

Studies of drug resistance of HL60 and HL60/Dnr cells in the presence of Hospicells. The Hospicells were seeded first at $60 \%$ confluency in a 96 -well flat-bottomed culture plate with complete medium containing 10\% FBS. After $18 \mathrm{~h}$ incubation, the leukemic cells $(10,000$ cells/well) were added and co-cultured for $24 \mathrm{~h}$ with Hospicells in the presence of IGF-I $(200 \mu \mathrm{g} / \mathrm{ml})$ or IGF-IR inhibitor $(1 \mu \mathrm{M}$ before addition of daunorubicin). The effect of these cytotoxic agents was evaluated by optical density (OD) measurement using the multi-well plate reader (Wallac, Perkin-Elmer, Waltham, MA, USA). The result is representative of three independent experiments.

Statistical analyses. The results are presented as mean $\pm \mathrm{SE}$ and data were analyzed using Student's t-test P-value $(<0.05$ was considered significant). 


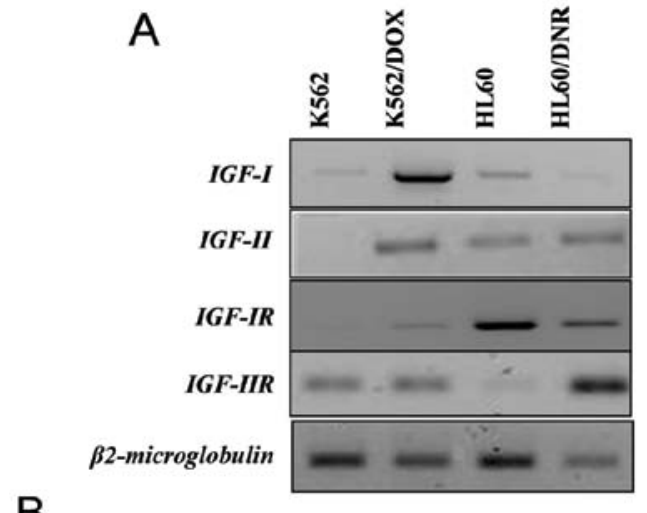

B
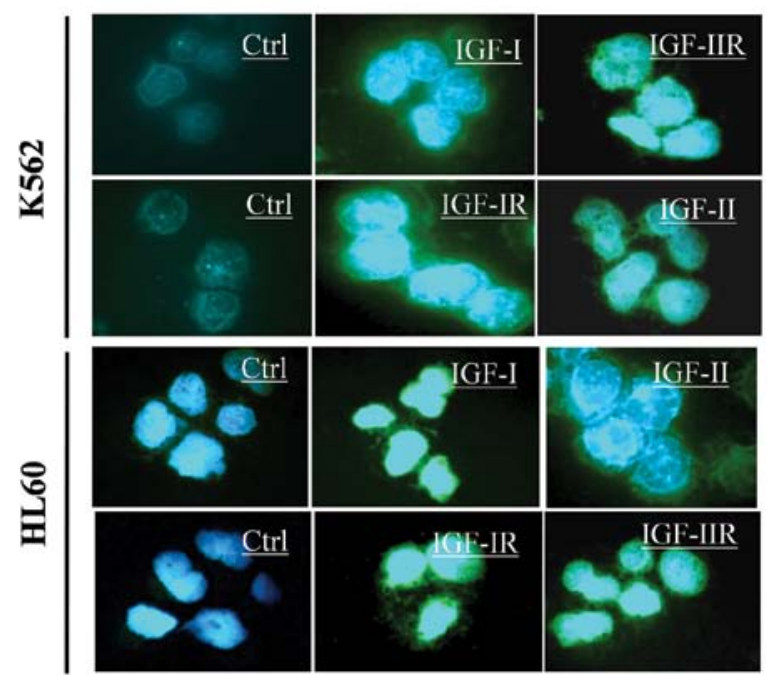

\begin{tabular}{cc}
\hline Cells & Dosage of IGF1 pg/ml \\
\hline RPMI medium Control & 0 \\
K562 & $<5$ \\
K562/D0x & 50 \\
HL60 & $<5$ \\
HL60/DNR & 10 \\
\hline
\end{tabular}

C
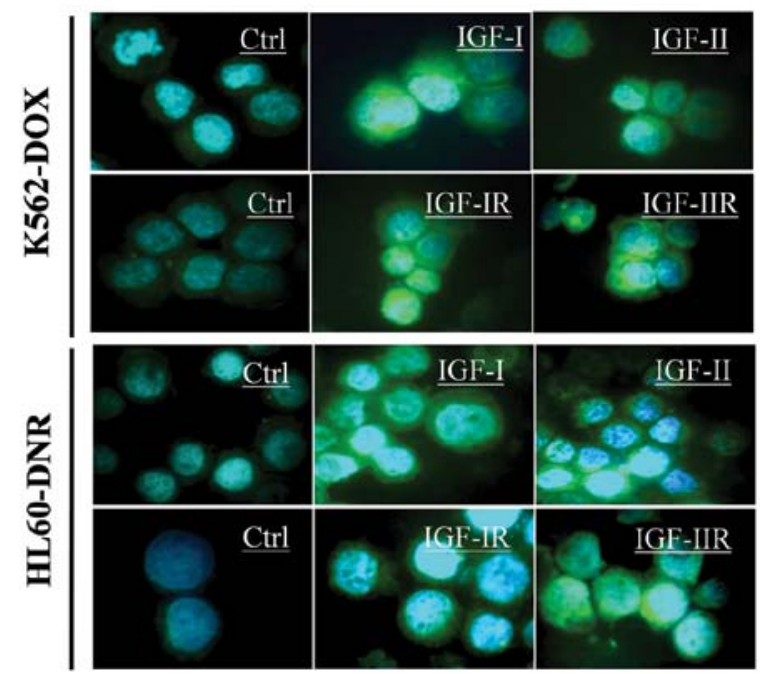

Figure 1. Expression of IGFs and IGF-R by the leukemic cells. IGF-I, -II, -IR and -IIR mRNA expression was studied by RT-PCR. $\beta 2$-microglobulin was used as control (A). The proteins of IGF family were analyzed by immunocytochemistry. As negative controls, the cells were incubated only with the secondary antibodies (B). The amount of IGF-I pg/ml in the supernatants of the sensitive and resistant leukemic cells was analyzed by ELISA (C).

\section{Results}

Expression of IGFs and IGF-R by leukemic cells. Fig. $1 \mathrm{~A}$ shows the four cell lines (HL60 and K562 sensitive and resistant) the difference in transcription levels of IGFs and their receptor genes. These results were confirmed at the protein level by immunocytochemistry (Fig. 1B and C). Fig. 1D indicates the amount of IGF-I in the supernatants of the sensitive and resistant cells. The results show that the resistant cells secrete more IGF-I $(50 \mathrm{pg} / \mathrm{ml})$ than the sensitive cells $(<5 \mathrm{pg} / \mathrm{ml})$.

Expression of P-gp by the sensitive and resistant cells. The $M D R 1$ gene coding P-gp protein was studied by the RT-PCR. Fig. 2A shows that MDR1 mRNA is strongly expressed by resistant cells whereas the sensitive cells not at all. These results were confirmed by flow cytometry of P-gp protein (Fig. 2B). The ratios of the Mean Fluorescence Intensity (MFI) of P-gp in resistant cells as against the value for controls are presented in Fig. 2C. Thus it can be inferred that the drug expulsion mechanism is active in the resistance cells and not in the controls.

The effect of IGF-I on cell proliferation. The effect of IGF-I on the proliferation rate of sensitive K562 and HL60 and resistant K562/Dox and HL60/Dnr cells are shown (Fig. 3A and B). The rate of proliferation of the sensitive cells was lower than that of the resistant ones. These results show that IGF-I promotes proliferation, its effect being more important in the resistant cells than in the sensitive cells.

We also determined the effect of the cyclolignan PPP, an IGF-IR inhibitor (22), on the resistant cells which express P-gp: HL60/Dnr (Fig. 3C) and K562/Dox (Fig. 3D) and sensitive cells K562 and HL60 which do not. The values of the $\mathrm{IC}_{50}$ of PPP in these cells were evaluated by MTT tests. Fig. 3E (see table inserted) shows that the value of the $\mathrm{IC}_{50}$ of PPP is higher in the resistant cells as compared to sensitive cells.

IGF-I mediated expression of MDRI mRNA and P-gp in the sensitive and resistant cells. Fig. 4A shows induction of MDR1 mRNA expression and its protein P-gp (Fig. 4B) in cells treated by IGF-1. This expression of P-gp, induced by IGF-I, is inhibited by the presence of PPP in both resistant and sensitive cells. The results suggest that IGF-I, via IGF-IR, is able to induce and control the expression of P-gp, the major protein implicated in chemoresistance.

Regulation of $A B C$ genes by IGF-I. Normally, the expression of $M R P 1, M R P 2, M R P 3$ and $B C R P$ is low or non-existent in the 4 cell lines (K562, K562/Dox, HL60 and HL60/Dnr), whereas MRP5 is strongly expressed (Fig. 5). In the K562 and 
A

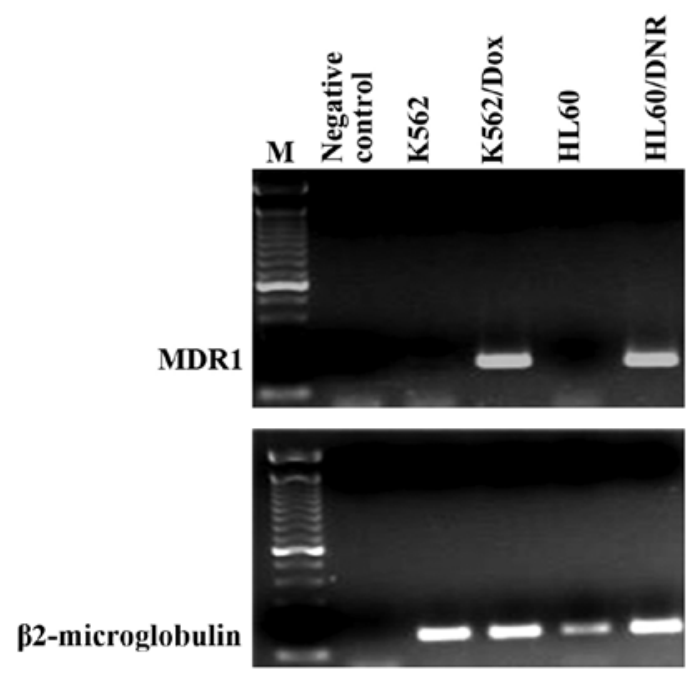

B

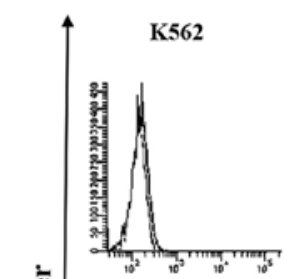

HL60

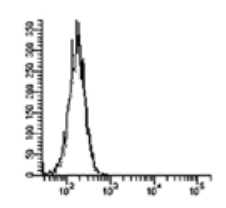

Immunofluorescence CD 243-PE

C

\begin{tabular}{lc}
\hline CELLS & MFI P-gp/MFI isotype \\
\hline K562 & 1.05 \\
K562/DOX & 26.2 \\
HL60 & 1.45 \\
HL60/DNR & 11.45 \\
\hline
\end{tabular}

Figure 2. Expression of P-gp by the leukemic cells. MDR1 mRNA expression was studied in K562, K562/Dox, HL60 and HL60/Dnr cells by RT-PCR using $\beta 2$-microglobulin as control (A). Flow cytometry analysis of P-gp in these cells using anti-CD243-phycoerythrin (B). P-gp expression was quantified as the mean fluorescence intensity (MFI) shift (ratio of the MFI of P-gp and isotype control) (C).

its derivative K562/Dox cells, the expression of $M R P 3$ and $B C R P$ increased significantly in the presence of IGF-I. On the other hand, the expression of MRP3 and BCRP, in these same cells decreases or disappears in the presence of PPP.

In HL60/Dnr, we found no significant difference in the expression of MRP1 mRNA in the presence of IGF-I, however, exposure to PPP in the medium led to the inhibition of $M R P 1$ gene expression. We found no difference in the expression of BCRP and MRP2 mRNAs in the HL60 cells and its derivative HL60/Dnr. Whereas, the expression of MRP5 gene was not affected by addition of IGF-I nor that of PPP.

Expression of IGF, IGF-R and MDRI by Hospicells. Hospicells from the stroma were identified because of their property to interact with HL60 cells. Fig. 6A shows HL60 interaction with a subset of stromal cells (Hospicells) and Fig. 6B with the enriched population of Hospicells. These cells express IGF-I, IGF-II, IGF-IR and IGF-IIR, as studied by immunocytochemistry (Fig. 6C) and P-gp (MDR-1) mRNA by RT-PCR (Fig. 6D).

Transcriptional regulation of the $A B C$ genes through the association of HL60 with Hospicells. The number of Hospicells was counted in each bone marrow stroma preparation. It varied from 3 to $9.7 \%$ of the total stromal cells. In normal bone marrow only $0.7 \%$ of stromal cells are Hospicells (data not shown). Three samples were chosen from AML bone marrow depending on the number of Hospicells (Fig. 7A). Fig. 7B shows that HL60 cells express mRNA for MDRl, $M R P 2$ and MRP3 in the presence of the Hospicells whereas it was not expressed in control cells. Moreover, the level of expression of $\mathrm{ABC}$ genes was directly related to the number of Hospicells present initially in the three BM samples. However, no difference in the expression of MRP5 in the presence of the Hospicells compared to the control was seen (Fig. 7C).

Fig. 7D and E show that HL60 cells co-cultivated with Hospicells from AML (N3 rich in Hospicells), express the $\mathrm{ABC}$ genes. On the other hand, the addition of PPP decreased the expression of $M D R 1$ and $M R P 1$ as also the $B C R P$.

These results are interesting since it may suggest that IGF-I was secreted by Hospicells or HL60 cells and acts through autocrine and/or paracrine mechanisms on MDRl, MRPI, $M R P 2$ and $B C R P$ genes.

Interaction between HL60 and Hospicells in the presence of IGF-I and induction of chemoresistance. Our results show that under culture conditions (without treatment), HL60 sensitive cell proliferation is stimulated by IGF-I $(\mathrm{P}=0.02)$ whereas this strongly diminishes in the presence of PPP $(\mathrm{P}=0.002)$. This indeed confirms our earlier results (Fig. 8A). In the presence of Hospicells, we observed a significant increased proliferative activity of HL60 cells ( $\mathrm{P}=0.03)$ as compared to controls. HL60 cells when in physical contact with the Hospicells display a clear resistance to daunorubicin. This resistance is reinforced further by IGF-I $(\mathrm{P}=0.03)$ whereas it decreases in the presence of PPP $(\mathrm{P}=0.02)$.

These observations confirm that, on one hand IGF-I regulates $\mathrm{ABC}$ gene expression (mainly MDRI), whereas Hospicells provide protection to HL60 leukemic cells against the effect of chemotherapy. Fig. 8B depicts the interaction between 

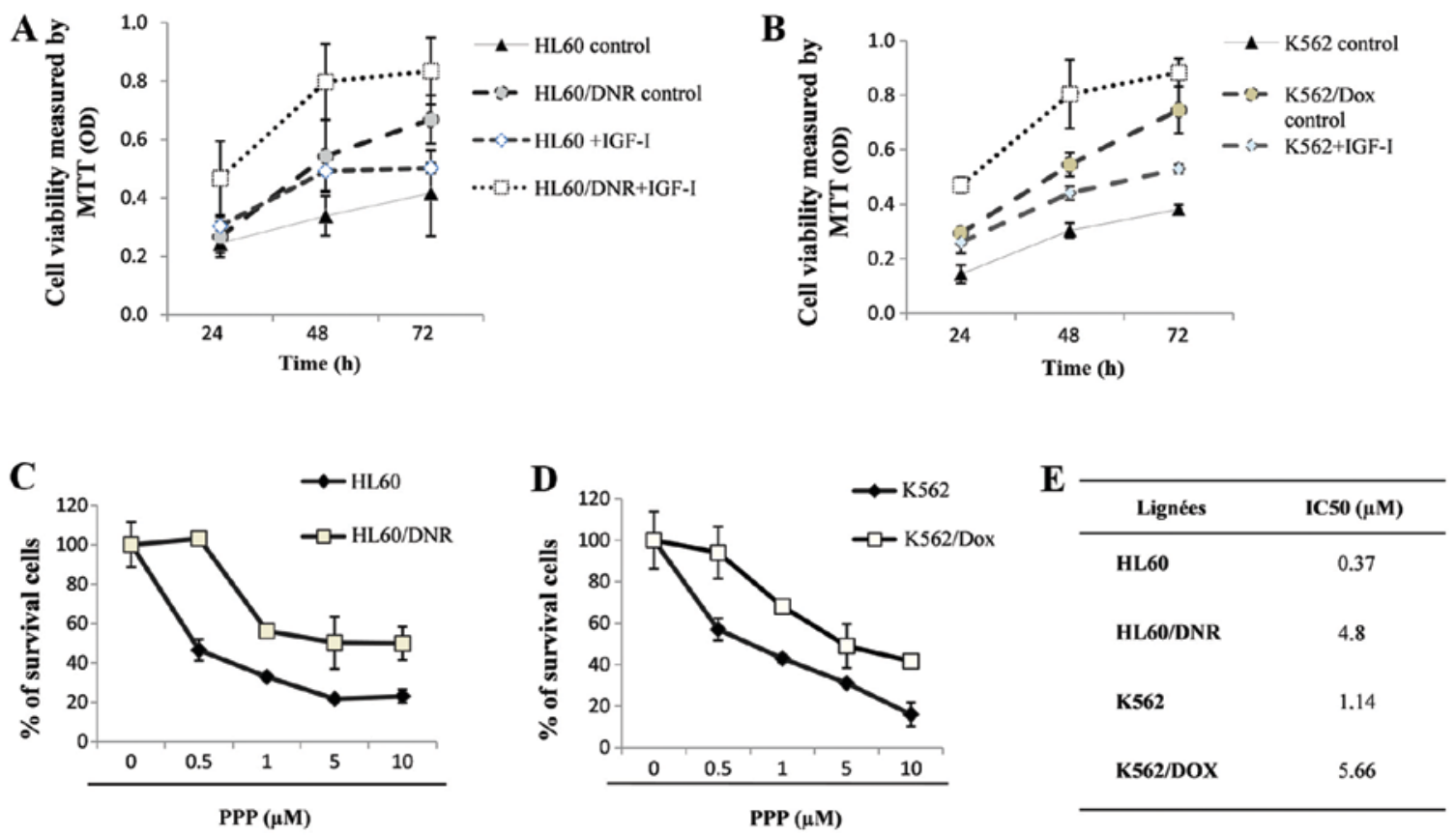

Figure 3. Effect of IGF-I on the proliferation of sensitive and resistant cells. K562 (A) and HL60 (B) were incubated in a culture medium without FBS (control) or in the presence of IGF-I ( $200 \mathrm{ng} / \mathrm{ml})$ during 24,48 and $72 \mathrm{~h}$ at $37^{\circ} \mathrm{C}$. Cell proliferation was studied by MTT. Effects of the inhibitor of IGF-IR (PPP) at various concentrations $(0,0.5,1,5$ and $10 \mu \mathrm{M})$ on the proliferation of sensitive and resistant K562 (C) and HL60 leukemic cells (D). The values of the IC 50 of PPP $\mu \mathrm{M}$ is presented for each cell type (E).

$\mathbf{A}$

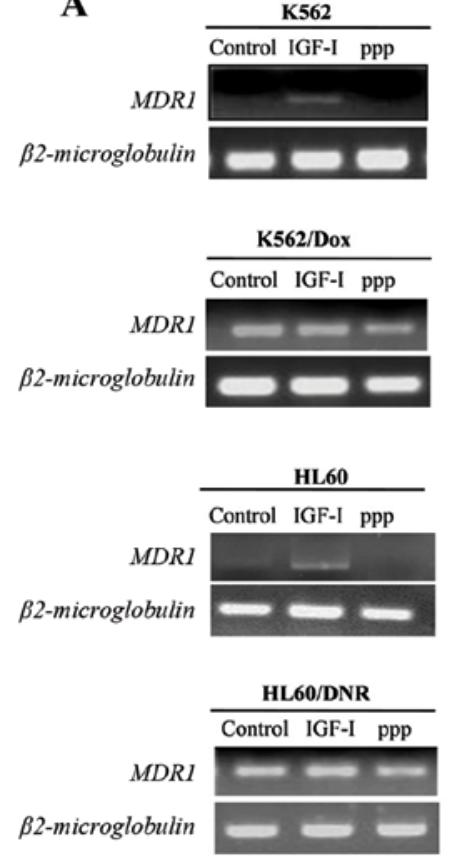

B
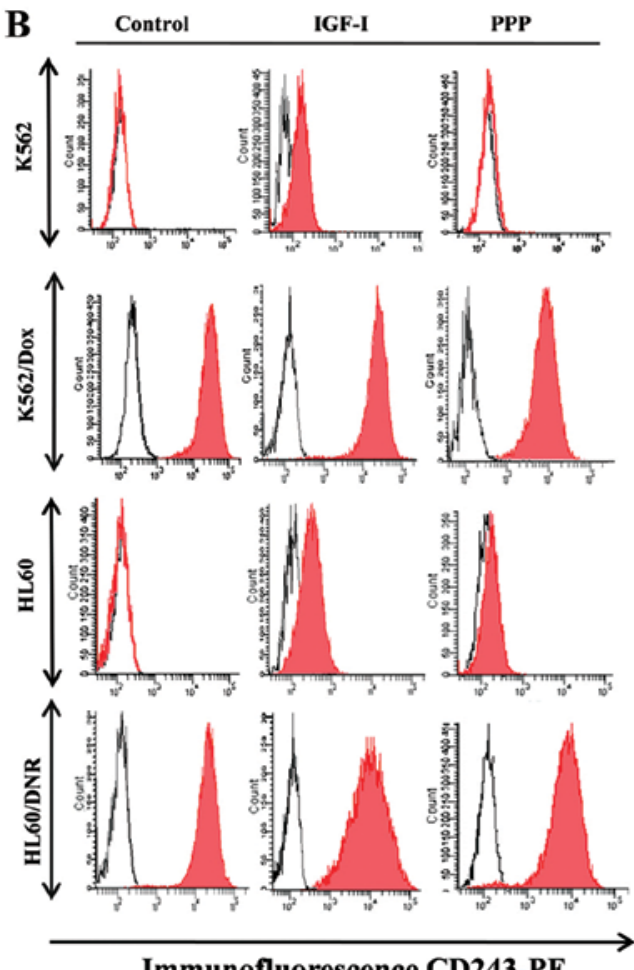
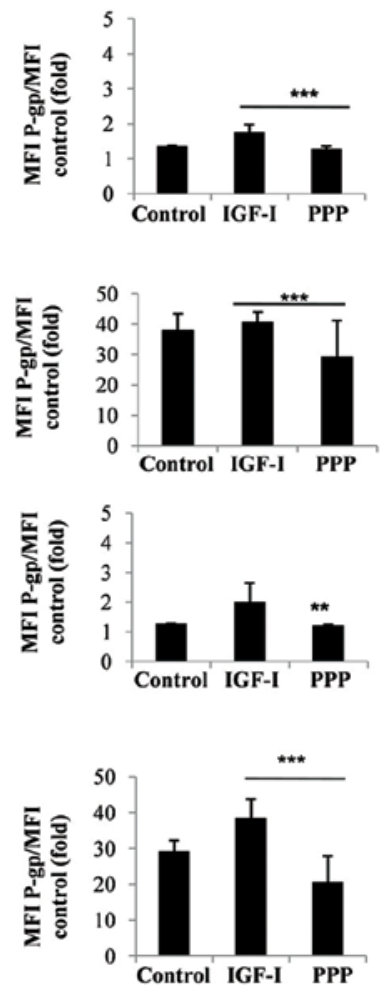

Figure 4. IGF-I controls the expression of $M D R I$ and P-gp in leukemic cells. The cell lines were incubated in the presence of IGF-I or PPP for $12 \mathrm{~h}$. The expression of $M D R 1$ was analyzed by RT-PCR (A). The expression of P-gp protein was studied by flow cytometry using anti-CD243-PE. Isotypic IgG2a was used as negative control (B).

HL60/Dnr cells and Hospicells in the presence of IGF-I and the enhancement of chemoresistance. It shows that proliferation of these resistant cells is stimulated by IGF-I $(\mathrm{P}=0.0002)$, whereas it decreases in the presence of PPP $(\mathrm{P}=0.0003)$. Thus the interaction between Hospicells and HL60/Dnr cells increases the proliferation of the resistance cells which is further amplified 

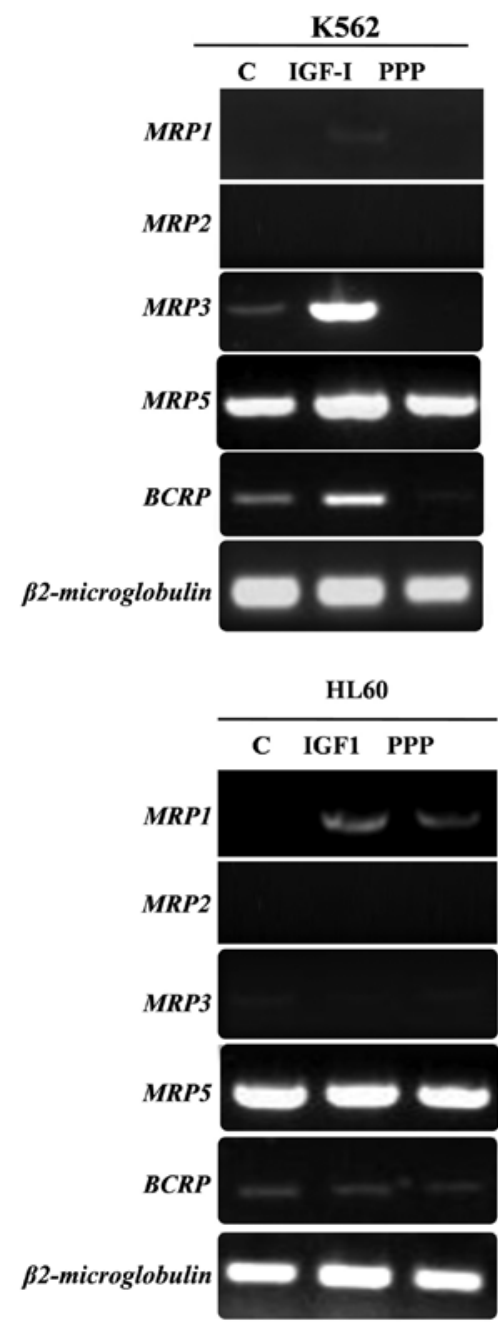
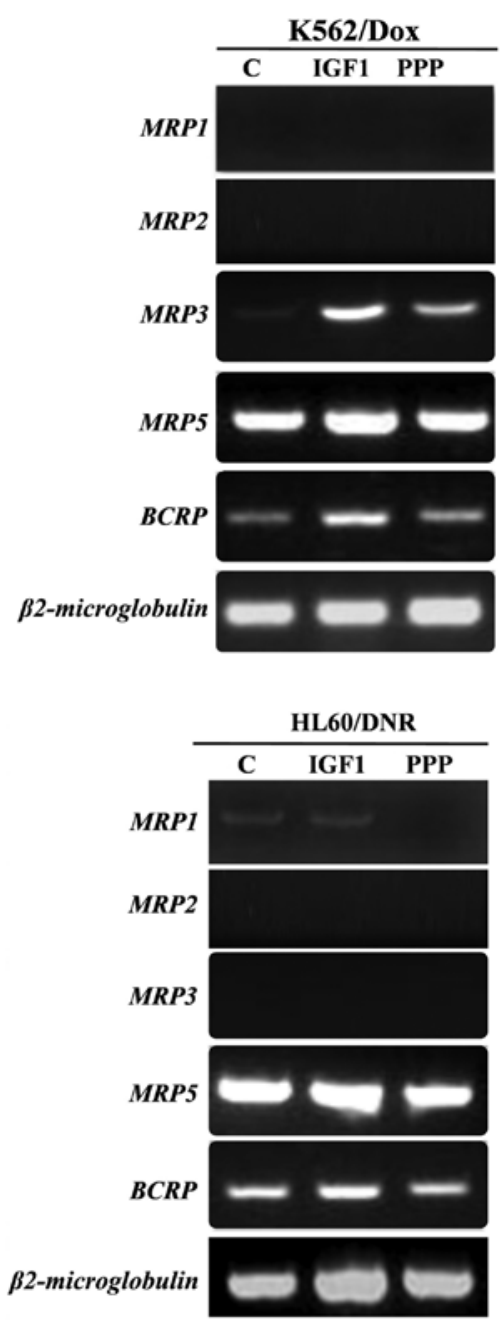

Figure 5. Regulation of the ABC genes by IGF-I. The four leukemic cell lines were incubated in the presence of IGF-I ( $200 \mathrm{ng} / \mathrm{ml})$ or PPP $(0.5 \mu \mathrm{M}$ for the HL60 and $\mathrm{K} 562 ; 1 \mu \mathrm{M}$ for K562/Dox and HL60/Dnr) for $12 \mathrm{~h}$ at $37^{\circ} \mathrm{C}$. Then, a RT-PCR was carried out to study the expression of mRNAs for $M R P 1, M R P 2, M R P 3$, $M R P 5$ and $B C R P$ with $\beta 2$-microglobulin as a control.
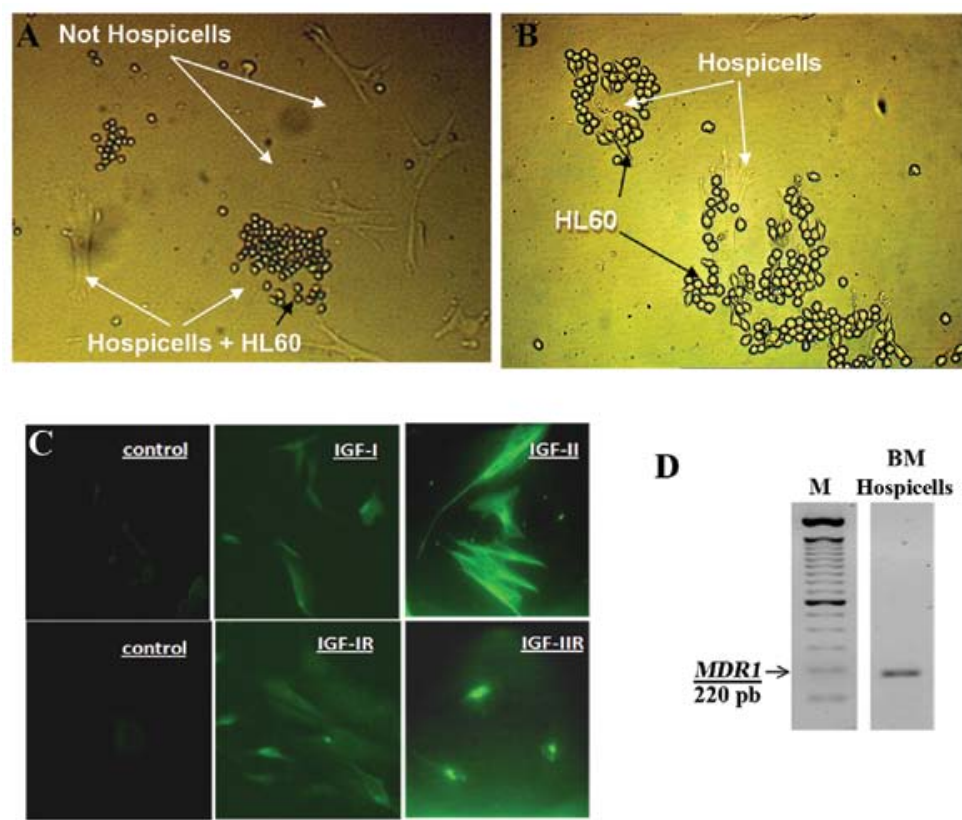

D

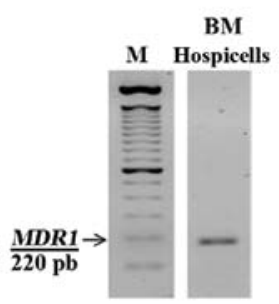

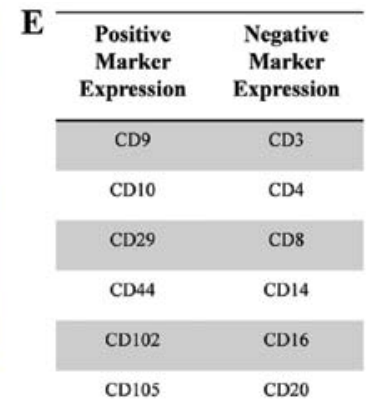

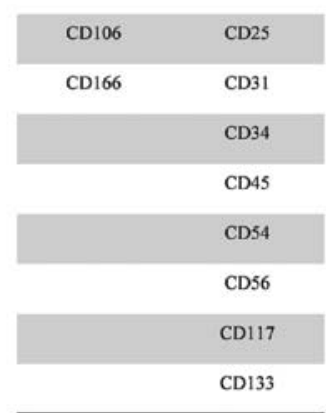

Figure 6. Expression of IGFs, IGF-R and MDR1 in Hospicells from AML bone marrow. Hospicells were identified among other stromal cells because of their property to interact with HL60 cells (A). Interaction of HL60 with enriched Hospicells (B). The Hospicells were stained by IGF-I, -II, -IR and -IIR antibodies (C). Expression of MDR1 by Hospicells was analyzed by RT-PCR (D). 
A
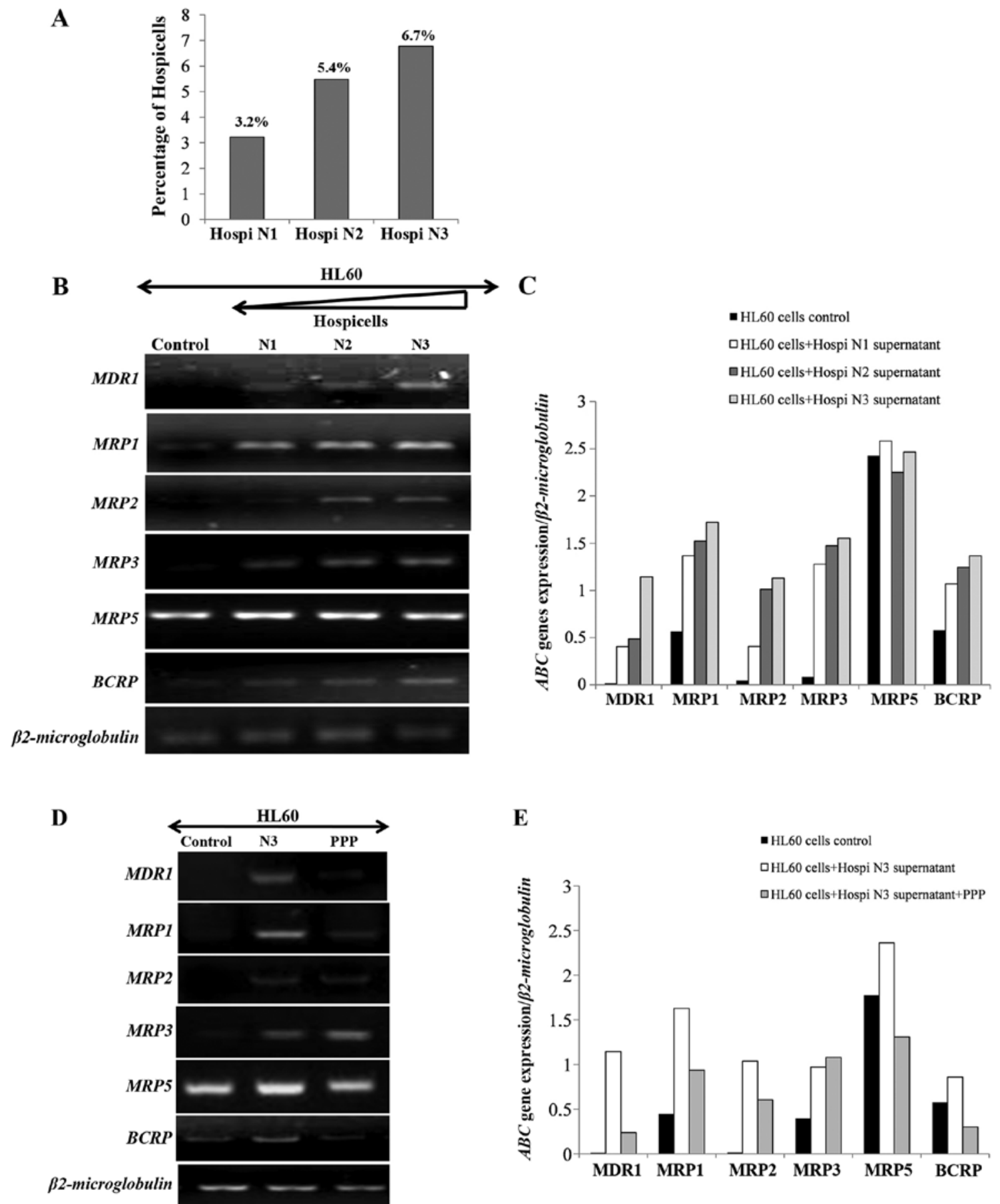

Figure 7. Expression of the ABC genes by HL60 cells co-cultivated with Hospicells. The Hospicells from three bone marrows of AML were counted and expressed as a percentage compared to the total number of mesenchymal stromal cells (A). HL60 cells co-cultivated with the Hospicells of three bone marrows for $12 \mathrm{~h}$ and the expression of ABC genes were analyzed by RT-PCR (B). The ratio of ABC gene expression/ $\beta 2$-microglobulin is presented in (C). HL60 cells co-cultivated with Hospicells from AML (N3) bone marrow for $12 \mathrm{~h}$ in presence or not of PPP, an RT-PCR was carried out to study the ABC gene expression: $M D R 1, M R P 1, M R P 2, M R P 3, M R P 5$ and $B C R P(\mathrm{D})$. The ratio of $\mathrm{ABC}$ gene expression/ $\beta 2$-microglobulin is presented in (E).

by the presence of IGF-I. The inhibition of IGF-IR by the addition of PPP reduces this drug resistance.

\section{Discussion}

Of the two insulin-like growth factors, IGF-I and IGF-II, IGF-I binds to two distinct cell surface receptors named IGF receptor-I (IGF-IR) and the insulin receptor (INSR).
The binding of IGF-I/IGF-IR occurs at a higher affinity than IGFI/INSR binding. IGF-IR is a transmembrane tyrosine kinase receptor and is activated by IGF-I and IGF-II (24-27).

IGF-II binds to the IGF-II receptor and acts as a signaling antagonist. IGF-I and IGF-II form complexes with insulinlike growth factor binding protein (IGFBP). Integrin $\alpha v \beta 3$ also plays an important role in IGF-IR signaling and its biological functions (28). Several studies have shown that 
A

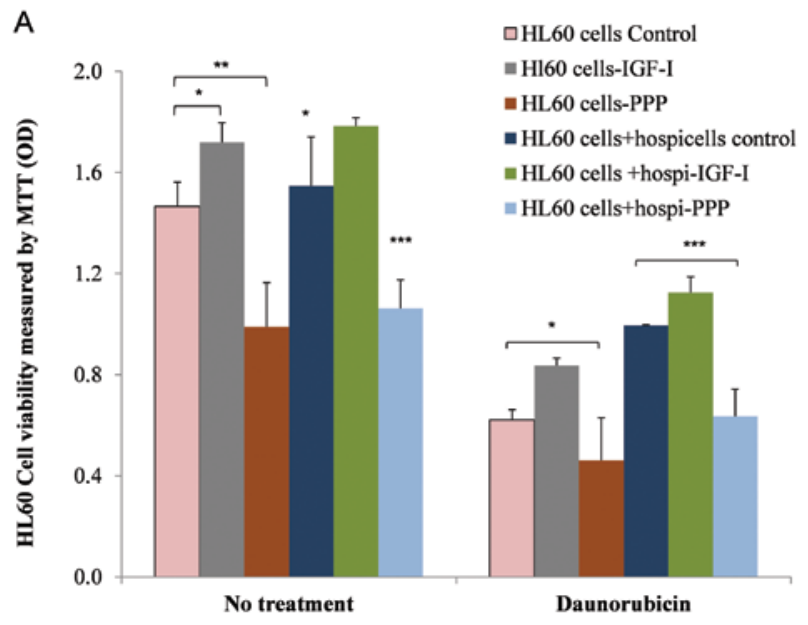

口HL60/DNR cells control

B

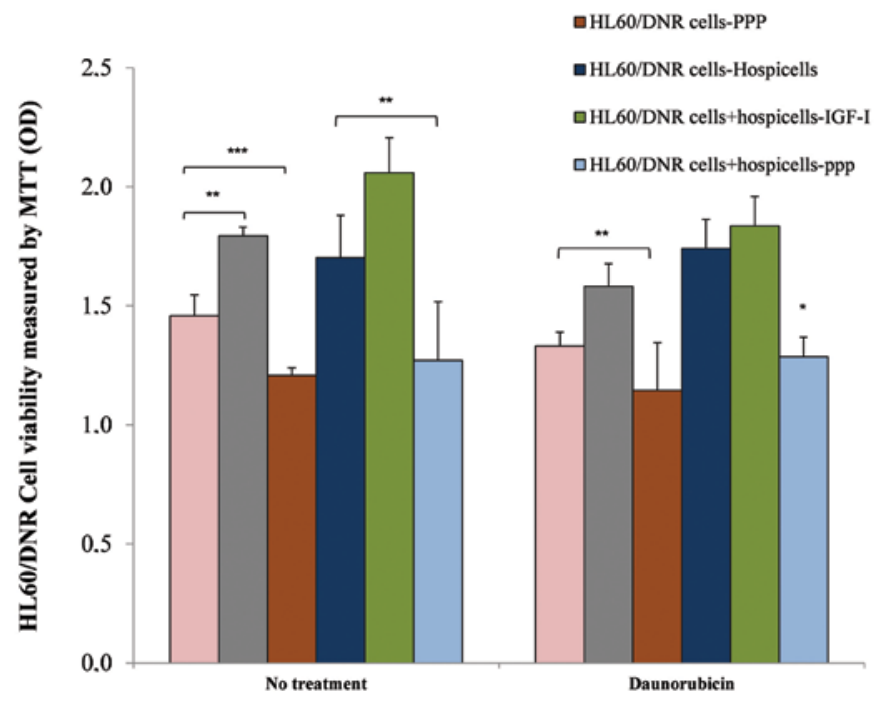

Figure 8. Hospicells protect HL60 cells against daunorubicin effect in the presence of IGF-I. HL60 was co-cultivated with Hospicells in the presence of IGF-I alone or with PPP. The chemotherapy agent, daunorubicin was added to the culture medium for $24 \mathrm{~h}$ (A). HL60/Dnr cells co-cultivated with Hospicells from AML N3 in the presence of IGF-I or PPP during $24 \mathrm{~h}$ and were incubated thereafter with daunorubicin (B). Average $\pm S E,(n=3)$, the difference in expression is significant $\left({ }^{*} \mathrm{P}<0.05,{ }^{*}{ }^{* *} \mathrm{P}<0.0005\right)$.

IGF-I is involved in the progression of malignant hematologic diseases (23).

During this study, the characteristics of the myeloid cell lines, both sensitive and resistant to the agents of chemotherapy, were defined by studying the expression of $M D R I$ and its protein P-gp. In addition, the proliferative effect of IGF-I on sensitive or resistant cells and the effect of the IGF-IR inhibitor (PPP) were ascertained. It was noted that the basal level of proliferation of the resistant cells was well above that of the sensitive cells. Exogenous addition of IGF-I stimulated proliferation of the two cell lines without marked difference.

The degree of resistance displayed by HL60 (in contact with Hospicells) was more pronounced when the proportion of Hospicells in givens stroma was high. This was partially abolished by the addition of PPP. However, MRP5 was an exception and remained unchanged. The addition of IGF-I increased the expression of $\mathrm{P}-\mathrm{gP}$ which could be inhibited again by PPP. The co-cultures of Hospicells with sensitive leukemic cells showed that the Hospicells were able to transmit the character of drug resistance to the sensitive cells. We had previously provided evidence that bone marrow stromal cells secrete significant amounts of FGF (fibroblast growth factor), SDF-1 $\alpha$ (stromal cell-derived factor 1) and IGF-1 (8). In the present study we report that bone marrow Hospicells also secrete IGF-1. Consequently, IGF (via autocrine or paracrine pathway) could be considered a strong candidate for the regulation of $\mathrm{ABC}$ genes and chemoresistance of HL60 cells.

In an unpublished study we had observed that the interaction of cancer cells with BMH was integrin-dependent. Cell-cell interaction activates integrin signaling pathway which play a crucial role in IGF signaling (28). The IGF-IR and its ligands may also promote growth of metastatic cells in the bone, the preferred site of metastases (29). Recently, we reported that Hospicells from solid tumors can be involved in chemoresistance via oncologic trogocytosis, i.e., through transfer of MDR proteins onto the incoming cancer cells (2) or upregulation of the ABC genes (3). The IGFs are among the more abundant growth factors in bone tissue and are synthesized by various bone marrow cells including stromal cells (8) and BMH. Within the microenvironment, the stromal Hospicells, in concert with IGF-1, provide strong synergetic effect for the maintenance and proliferation of cancer cells. In addition, $\mathrm{BMH}$ may represent a niche for homing of cancer cells and the secretion of IGF-1 which provide protection while promoting their proliferation and chemoresistance.

Our results demonstrate that tumor stromal cells contribute in the physiopathological response to IGF-1/IGF-1R. Targeting IGF-1R in multiple myeloma (30) and breast cancer (31) indicated a decrease in the formation of tumors and a diminuation of angiogenesis. In view of the scant attention given so far to the role of microenvironment, in the behavior and biology of the leukemic cells, we have focused attention in the present study on the intimate relationships between Hospicells, IGF-1 and malignant cells.

IGF and IGF1R expression levels are relevant indicators of tumor stage and/or disease progression. Additional studies will be necessary to further clarify the mode of action of the ABC pumps as also other pumps such as LRP (lung resistancerelated protein). Curiously IGF seems not to have any effect on MRP5 gene expression.

In conclusion our results suggest the importance of the microenvironment and the IGF-I pathway in drug resistance of leukemic cells. A better knowledge of this close relationship can be helpful in the search for new openings in cancer therapy.

\section{References}

1. Baudard M, Beauchamp-Nicoud A, Delmer A, Rio B, Blanc C, Zittoun R and Marie JP: Has the prognosis of adult patients with acute myeloid leukemia improved over years? A single institution experience of 784 consecutive patients over a 16-year period. Leukemia 13: 1481-1489, 1999.

2. Rafii A, Mirshahi P, Poupot M, Faussat AM, Simon A, Ducros E, Mery E, Couderc B, Lis R, Capdet J, Bergalet J, Querleu D, Dagonnet F, Fournié JJ, Marie JP, Pujade-Lauraine E, Favre G, Soria J and Mirshahi M: Oncologic trogocytosis of an original stromal cells induces chemoresistance of ovarian tumours. PLoS One 3: e3894, 2008. 
3. Lis R, Capdet J, Mirshahi P, Lacroix-Triki M, Dagonnet F, Klein C, Mirshahi M, Fournié JJ, Rafii A and Poupot M: Oncologic trogocytosis with Hospicells induces the expression of N-cadherin by breast cancer cells. Int J Oncol 37: 1453-1461, 2010.

4. Benabbou N, Mirshahi P, Cadillon M, Soria J, Therwath A and Mirshahi M: Hospicells promote upregulation of the ATP binding cassette genes by insulin like growth factor-I via JAK2STAT3 signaling pathway in ovarian cancer cell line. Int J Oncol 43: 685-694, 2013

5. Pasquet M, Golzio M, Mery E, Rafii A, Benabbou N, Mirshahi P, Hennebelle I, Bourin P, Allal B, Teissie J, Mirshahi M and Couderc B: Hospicells (ascites-derived stromal cells) promote tumorigenicity and angiogenesis. Int J Cancer 126: 2090-2101, 2010.

6. Martinet L, Poupot R, Mirshahi P, Rafii A, Fournié JJ, Mirshahi M and Poupot M: Hospicells derived from ovarian cancer stroma inhibit T-cell immune responses. Int J Cancer 126: 2143-2152, 2010.

7. Castells M, Thibault B, Mery E, Golzio M, Pasquet M Hennebelle I, Bourin P, Mirshahi M, Delord JP, Querleu D and Couderc B: Ovarian ascites-derived Hospicells promote angiogenesis via activation of macrophages. Cancer Lett 326: 59-68, 2012.

8. Mirshahi P, Rafii A, Vincent L, Berthaut A, Varin R, Kalantar G, Marzac C, Calandini OA, Marie JP, Soria C, Soria J and Mirshahi M: Vasculogenic mimicry of acute leukemic bone marrow stromal cells. Leukemia 23: 1039-1048, 2009.

9. Wu X, Tortolero-Luna G, Zhao H, Phatak D, Spitz MR and Follen M: Serum levels of insulin-like growth factor I and risk of squamous intraepithelial lesions of the cervix. Clin Cancer Res 9: 3356-3361, 2003.

10. Yang SY and Winslet M: The IGF system in carcinogenesis and its implication for cancer therapy. Curr Oncol 18: 301-302, 2011.

11. Samani AA, Yakar S, Le Roith D and Brodt P: The role of he IGF system in cancer growth and metastasis: overview and recent insights. Endocr Rev 28: 20-47, 2007.

12. Héron-Milhavet L and LeRoith D: Insulin-like growth factor induces MDM2-dependent degradation of p53 via the p38 MAPK pathway in response to DNA damage. J Biol Chem 277 $15600-15606,2002$.

13. He Y, Zhang J, Zheng J, Du W, Xiao H, Liu W, Li X, Chen X, Yang $L$ and Huang S: The insulin-like growth factor-1 receptor kinase inhibitor, NVP-ADW742, suppresses survival and resistance to chemotherapy in acute myeloid leukemia cells. Oncol Res 19: 35-43, 2010.

14. Abe S, Funato T, Takahashi S, Yokoyama H, Yamamoto J, Tomiya Y, Yamada-Fujiwara M, Ishizawa K, Kameoka J, Kaku M, Harigae $\mathrm{H}$ and Sasaki T: Increased expression of insulin-like growth factor 1 is associated with Ara-C resistance in leukemia. Tohoku J Exp Med 209: 217-228, 2006.

15. Kuhn DJ, Berkova Z, Jones RJ, Woessner R, Bjorklund CC, Ma W, Davis RE, Lin P, Wang H, Madden TL, Wei C, Baladandayuthapani $\mathrm{V}$, et al: Targeting the insulin-like growth factor-1 receptor to overcome bortezomib resistance in preclinical models of multiple myeloma. Blood 120: 3260-3270, 2012.

16. Guo YS, Jin GF, Houston CW, Thompson JC and Townsend CM Jr: Insulin-like growth factor-I promotes multidrug resistance in MCLM colon cancer cells. J Cell Physiol 175: 141-148, 1998.
17. Schwarze CP, Neu S, Beck J, Mavridou K, Ranke MB and Binder G: Influence of IGF-I and cell density on MDR1 expression in the T-lymphoblastoid cell line CCRF-CEM. Horm Res 52: 192-199, 1999.

18. Shimon I and Shpilberg O: The insulin-like growth factor system in regulation of normal and malignant hematopoiesis. Leuk Res 19: 233-240, 1995.

19. Doepfner KT, Spertini O and Arcaro A: Autocrine insulin-like growth factor-I signaling promotes growth and survival of human acute myeloid leukemia cells via the phosphoinositide 3-kinase/Akt pathway. Leukemia 21: 1921-1930, 2007.

20. Baier TG, Jenne EW, Blum W, Schönberg D and Hartmann KK: Influence of antibodies against IGF-I, insulin or their receptors on proliferation of human acute lymphoblastic leukemia cell lines. Leuk Res 16: 807-814, 1992

21. Gilmore MJ, Prentice HG, Blacklock HA, Janossy G and Hoffbrand AV: A technique for rapid isolation of bone marrow mononuclear cells using Ficoll-Metrizoate and the IBM 2991 blood cell processor. Br J Haematol 50: 619-626, 1982.

22. Girnita A, Girnita L, del Prete F, Bartolazzi A, Larsson O and Axelson M: Cyclolignans as inhibitors of the insulin-like growth factor-1 receptor and malignant cell growth. Cancer Res 64: 236-242, 2004.

23. Qiang YW, Kopantzev E and Rudikoff S: Insulin like growth factor-I signaling in multiple myeloma: downstream elements, functional correlates, and pathway cross-talk. Blood 99: 4138-4146, 2002.

24. Rodon J, DeSantos V, Ferry RJ Jr and Kurzrock R: Early drug development of inhibitors of the insulin-like growth factor-1 receptor pathway: lessons from the first clinical trials. Mol Cancer Ther 7: 2575-2588, 2008.

25. Gregory CW, DeGeorges A and Sikes RA: The IGF axis in the development and progression of prostate cancer. Recent Res Dev Cancer 3: 437-462, 2001.

26. Macaulay VM: Insulin-like growth factors and cancer. Br J Cancer 65: 311-320, 1992.

27. Burren CP, Berka JL, Edmondson SR, Werther GA and Batch JA: Localization of mRNAs for insulin-like growth factor-I (IGF-I), IGF-I receptor, and IGF binding proteins in rat eye. Invest Ophthalmol Vis Sci 37: 1459-1468, 1996.

28. Clemmons DR and Maile LA: Integral membrane proteins that function coordinately with the insulin-like growth factor I receptor to regulate intracellular signaling. Endocrinology 144: 1664-1670, 2003.

29. Turner HE, Harris AL, Melmed S and Wass JA: Angiogenesis in endocrine tumors. Endocr Rev 24: 600-632, 2003.

30. Wu KD, Zhou L, Burtrum D, Ludwig DL and Moore MA: Antibody targeting of the insulin like growth factor I receptor enhances the anti-tumor response of multiple myeloma to chemotherapy through inhibition of tumor proliferation and angiogenesis. Cancer Immunol Immunother 56: 343-357, 2007.

31. Karamouzis MV and Papavassiliou AG: Targeting insulin-like growth factor in breast cancer therapeutics. Crit Rev Oncol Hematol 84: 8-17, 2012.

32. Hopkins A, Crowe PJ and Yang JL: Effect of type 1 insulin-like growth factor receptor targeted therapy on chemotherapy in human cancer and the mechanisms involved. J Cancer Res Clin Oncol 136: 639-650, 2010. 